\title{
The Budgetary and Welfare Consequences of Security Co-Operation in the Southern Hemisphere: A South African Perspective
}

\author{
DR ANDRÉ ROUX \\ Director, Institute for Futures Research, University of Stellenbosch
}

\section{INTRODUCTION}

The end of the Cold War, new global circumstances, and the democratisation process in South Africa have resulted in a transformation of the way in which defence matters in this country are evaluated and approached. From 1960 to the end of the 1980 s defence spending decisions in South Africa were largely influenced by non-economic considerations, such as the perceived need to protect national values from foreign aggression and internal threats to stability, the ideological inclination of the government of the day, and a sense of inertia and incrementalism in respect of defence budgets. However, since 1989 the greater unlikelihood of an imminent foreign act of conventional aggression against the country and the advent of multi-party democracy, have served to highlight the possible trade-off between defence and socio-economic welfare (the so-called 'guns versus butter' debate). Indeed, since the end of the 1980s real defence expenditure in South Africa has declined by almost 60 percent, while the defence burden (defence expenditure as a percentage of gross domestic product) has fallen to below 2,0 percent.

In short, whereas prior to 1990 government resources were allocated to the defence effort with little regard for the sacrifice incurred in terms of the reduced availability of other (non-military) goods and services, in view of the current and future expected absence of any significant prospects of hostility, there is a desire and tendency to allocate scarce resources to civilian uses, such as investment in socio-economic infrastructure. It appears likely, therefore, that economic and socio-economic imperatives will - at least in the short to medium term - play a dominant role in determining the magnitude of defence budgets in South Africa.

However, the volume of resources allocated to defence may in future also be influenced by a factor that thus far has not been relevant. The reversal of the international ostracization of South Africa has arguably paved the way for extensive security co-operation between nations in the Southern Hemisphere. Collective security needs (augmented by 
the virtually universal desire and imperative to reduce individual defence budgets) could even culminate in the establishment of a Southern Hemisphere defence alliance along the lines of the North Atlantic Treaty Organisation (NATO). Regional powers such as South Africa, India and Argentina may be involved, together with countries such as Uruguay, Pakistan, Mozambique, Zimbabwe, Angola, Kenya and Tanzania.

The prospect of Southern Hemisphere security co-operation and, in particular, South Africa's involvement therein, raises a number of issues, viz.:

- The potential impact of co-operation on the defence burdens (and, by implication, other forms of government spending) of member countries, especially South Africa.

- The induced incentive for the various co-operating members to free ride (ie, for a given country to rely to a large degree on other members for its defence).

- The regional impact of security co-operation on overall economic and socio-economic welfare.

The main purpose of this paper is to examine the implications of security co-operation and, in particular, the financial consequences for South Africa in the event of her becoming involved in regional defence co-operation. To this end, a theoretical model of alliance forming is presented, after which the possible implications, largely of a speculative nature, and based on the premises of the theoretical model, of South Africa's participation in a security alliance are probed.

\section{A CAUSAL ANALYSIS OF DEFENCE EXPENDITURE WITHIN A PUBLIC SECTOR FRAMEWORK}

The conventional account of a country's national security policy assumes that a rational state balances the welfare of extra security with the opportunity cost of military

\begin{tabular}{|c|c|}
\hline Political imperatives & $\begin{array}{l}\text { Lobbying by military-industrial complex } \\
\text { Ideological inclination of government and national identity } \\
\text { Inertia and incrementalism }\end{array}$ \\
\hline Rconomic imperatives & $\begin{array}{l}\text { Level of economic development } \\
\text { Real income } \\
\text { Size of state budget } \\
\text { Indebtedness } \\
\text { Availability of foreign exchange } \\
\text { Foreign trade }\end{array}$ \\
\hline Military imperatives & $\begin{array}{l}\text { External security } \\
\text { Civil war and internal repression } \\
\text { Alliances }\end{array}$ \\
\hline
\end{tabular}

Table 1: Potential influences on defence expenditure 
expenditure. This approach implies a demand function for a good that generally displays the characteristics associated with public goods. As such, defence is largely provided by governments who consider a range of variables in determining the relative importance of defence amongst public expenditure categories. The purpose of this section is to consider, from a conceptual as well as empirical point of view, the various factors that may influence government's defence spending decisions.

The factors identified by various authors (Smith, 1980b; Whynes, 1979; Maizels and Nissanke, 1986; McKinlay, 1989; Davis and Chan, 1990; Deger, 1986; Pilandon, 1987; and Lotz, 1970) as having a potential influence on levels of and changes in defence spending, are classified in Table 1 according to political, economic and military considerations.

In some instances, only one or two of the forces may have a bearing on defence expenditure decisions; in others the majority may be germane. In addition, the relative importance of the factors may change over time within specific countries. For the sake of expedience, each factor will be discussed individually.

\section{Political imperatives}

Inasmuch as the military sector is closely interrelated with the civilian economy (for example, a government might place weapons production contracts with private firms; and soldiers spend their wages in civilian markets); and the sector is often a major area of the economy under the direct control of the central government, it may serve as an ideal fiscal regulator (Whynes, 1979: 26-27). Economic expansion can, for example, be effected immediately by the (government) ordering of a new weapons system, while excessive expansion can be countered by the cancellation or contraction of a defence project. Once this system has been established several groups of people, who collectively comprise the military-industrial complex (including senior defence force officers, owners and managers of defence-related industries, and politicians with defence sector links) will find it economically beneficial to lobby for its maintenance (Smith, 1989:347). However, this theory relies heavily on the existence of an economic surplus which, according to Whynes (1979:29), is unlikely in developing nations. Consequently, the ability of the militaryindustrial complex in developing countries to maintain defence spending at a certain level is limited.

According to Maizels and Nissanke (1986) and Whynes (1979) the military establishments of developing nations may take on an ideological function by, for example, attempting to create a national image of a modern state which could attract foreign capital; or by disseminating specific doctrines and social attitudes to conscripts. A sine qua non for the success of such a function is a high degree of control exercised over the military by the government.

Cooper (1990: 76-77) claims that 'inertia' may have a key influence on defence spending. If past expenditures have been relatively high, then national governments find it 
difficult to lower the current rate of spending. He states that: 'There is a preference for something near the status quo - not to disturb too much'. (Cooper, 1990:77). Smith (1989:347) extends this argument to the principle of incrementalism, whereby bargaining over the defence budget for a particular year starts from the status quo.

\section{Economic imperatives}

The first a priori linkage between defence expenditure and the level of economic development can be related to Wagner's law. Adolf Wagner argued that the '....pressure for social progress and resulting changes in the relative spheres of private and public economy....' (Eckstein, 1973:6) would result in a positive and rising relation between state activity and economic growth. Higher levels of development imply structural changes in society, greater urbanisation, greater inequalities in wealth, income and opportunities for advancement, and consequently greater potential for conflict between different groups within society.

Moreover, as real incomes rise, the demand for both private and social goods can generally be expected to increase in absolute terms. There is, however, a shift in the pattern of consumer wants in favour of relatively more social goods and relatively fewer private goods. The rationale behind this alteration in consumer wants is to be found in the gradual transformation of a poor society into a more prosperous economy (McConnell, 1966:682). In the pursuit of subsistence a poor society, dominated by agriculture, consumes virtually its entire real income in the form of basic private goods. Once these fundamental needs have been met, any surplus generated by the growing wealth of society is used to satisfy a series of less pressing but nonetheless important new needs, many of which are of a social nature. For example, increasing industrialisation and urbanisation due to economic grcwth create a demand for sanitation, street lights and the like, which in a poorer agrarian society would be provided by each family for itself, if at all. Industrialisation and urbanisation also lead to increasing human interdependence and greater socioeconomic complexity, thereby creating the potential for conflict. Consequently, government may, to a rising degree, be called upon to regulate financial transactions and to act as arbiter in the event of disputes and disagreements. The increased availability of leisure in a more opulent society is also likely to enhance the demand for education and training facilities. Finally, while a poor society spends little or nothing on formalised defence (due to a lack of resources), prosperity transforms armaments expenditure into an important social good. Thus, the government becomes more security conscious and increases its activities in the fields of policing and defence. On the other hand, if real income is stagnating, then, in the absence of foreign military or financial aid, the resource constraint is likely to place a limit on additional defence expenditure (Maizels and Nissanke, 1986:11291130). 
A factor related to the above is the importance of the government sector in the total economy. In countries where the share of government expenditure in GDP is relatively large the share of military expenditure in GDP is also likely to be relatively high (Maizels and Nissanke, 1986:1130). Whilst not disagreeing with this conclusion, McKinlay (1989:3238) contends that the relationship between military expenditure and total government expenditure may be spurious as '.....it is not so much that larger budgets drive larger higher military spending but that the latter results in the former.' (McKinlay, 1989:38). McKinlay, also hypothesises (1989:33-35) that larger budget deficits and concomitant rising levels of government indebtedness, which result in higher debt-servicing government allocations, restrict to some extent the scope for government expenditure and therefore reduce levels of military expenditure.

The relevance of foreign exchange is derived from the need of many developing countries to purchase military equipment from industrialised nations. In the absence of major financial aid developing countries with sustained balance of payments deficits would have to either curtail their military modernisation/expansion programmes, or finance them by restricting imports for civilian purposes (Maizels and Nissanke, 1986:1130).

\section{Military imperatives}

The primary purpose of a country's defence force is protect that country against possible external aggression. Historically this external security consideration explains a substantial proportion of the rapid growth in defence expenditure observed at different times throughout the world (for example, in the USA in the early 1950s, owing to the Korean War; in the Middle East, due to the Arab-Israeli conflict in this region from the mid-1950s; and in Africa since the early 1960 s, owing to the need to preserve the integrity of newlyindependent nations). External security considerations (related to the possible future intentions of the Soviet Union and black African states toward South Africa) played an important role in the rapid surge in South African defence expenditure during the early $1960 \mathrm{~s}$ and mid-1970s.

In developing nations in particular, the military is also an important force in the maintenance of political sovereignty within a country. The level of military expenditure in developing nations can therefore be related, in part at least, to the need for military forces to maintain ruling éiites in power (Maizels and Nissanke, 1986:1128). When a dichotomy exists with regard to the distribution of wealth between the élite, who control the means of production and have a monopoly on political power, and the mass of the population, the potential for instability in the system may result in the use of military repression. The expansion of the South African defence budget in the 1960s and 1970s may be partly attributed to the desire to contain political insurrection and civil unrest, and even the threat of civil war.

It can be argued that the level of defence expenditure may be influenced by whether or 
not a country is a member of a military alliance. However, the impact of alliance membership on defence spending is country-specific as it is dependent upon a wide range of considerations, such as the publicness of other members' defence output, the extent of spillins, the dilution of forces due, inter alia, to the geographical allocation of member countries, and the propensity towards free-riding. Defence goods produced by a member of an alliance potentially yield three kinds of benefits; private defence benefits to the ally; damagelimiting protection in the event of a conventional attack; and deterrence benefits.

Defence goods yielding private benefits (such as protection of coastal waters, the development of an arms industry, assistance in times of national disaster, and international prestige) comply with the public good conditions of non-rivalry and non-excludability within nations, but are private between allies (Hansen et al, 1990:39). in the case of defence goods providing damage-limiting protection (ie, the fending off of an assault by means of military action), dilution of forces results when protective forces are used to protect a larger front or border, ie, protective weapons may suffer a diminution in quality and/or quantity, depending on the range and accuracy of weapons, the topographical characteristics of the front's terrain and the relative concentration and location of allies or enemies. Thus, rivalry may prevail to some degree due to spatial considerations. Moreover, excludability may be readily practised with protective weapons as protection of an ally may be withheld at will and forces deployed elsewhere The possible non-adherence to the principles of non-rivalry and non-excludability suggests that protective defence goods tend to be impurely public (Sandler, 1997:445).

A defence good yields deterrence benefits to the alliance when its purpose is to convey a credible threat of retaliation on behalf of the alliance (see, for example, Boyer,

\begin{tabular}{|c|c|c|}
\hline & $\mathrm{r}=\frac{p p}{p p+i p+p r}$ & \\
\hline$r=0$ & $0<r<1$ & $r=1$ \\
\hline$p p=0$ & $0<p p<1$ & $p p=1$ \\
\hline$i p=0$ & $0<i p<1$ & $i p=0$ \\
\hline$p r=1$ & $p r=0$ & $p r=0$ \\
\hline $\begin{array}{l}\text { Private defence goods } \\
\text { (protection of coastal } \\
\text { waters, international } \\
\text { prestige) }\end{array}$ & $\begin{array}{c}\text { Impure public defence } \\
\text { goods } \\
\text { (protection) }\end{array}$ & $\begin{array}{c}\text { Pure public defence goods } \\
\text { (deterrence) }\end{array}$ \\
\hline $\begin{array}{l}\text { Rivalry and excludability } \\
\text { exist }\end{array}$ & $\begin{array}{l}\text { Goods subject to dilution } \\
\text { (ie, rivalry) and alternative } \\
\text { deployment }\end{array}$ & $\begin{array}{c}\text { Non-rivalry } \\
\text { Non-excludability }\end{array}$ \\
\hline
\end{tabular}

Table 2: Continuum of publicness of defence goods in an alliance 
1990:246-249). In particular, if the alliance's commitment to retaliate against an act of aggression directed at any member is credible to the potential aggressor, the threat embodied in the deterrent defence good provides non-rival benefits to the entire alliance (Sandler, 1977:446). In addition, if the alliance is perceived to be unified by the aggressor, the benefits accruing from the defence good cannot be withheld from any individual member of the alliance. Thus, defence goods that are of a deterrent (ie, retaliatory) nature can fulfill both conditions of a pure public good.

The analysis thus far is depicted in Table 2 which shows the continuum of values between 0 and unity that can be obtained by measuring the ratio $(r)$ of pure public defence (ie, deterrence) components, $p p$, to the sum of pure public defence, impure public defence (ie, protection), ip; and private defence components, $p r$. Private defence goods are situated on the left-hand side of the spectrum, and pure public defence goods on the right-hand side. Any point between these two extremes refers to impure public defence goods whose exact location on the continuum will be determined by the degree of rivalry and excludability.

This categorisation of (and distinction between) various forms of defence goods represents a departure from conventional analysis which merely differentiates between private and public defence goods (see, for example, Sandler, 1977; Murdoch and Sandler, 1984; McGuire, 1990; Boyer, 1990; and Hilton and Vu, 1991). Contemporary research, in turn, is more discriminating than initial models of alliance burden-sharing which assumed that all forms of alliance defence were of a public good nature (the seminal work in this regard was that of Olson and Zeckhauser, 1966).

Further refinements and specifications of the spectrum analysis presented in Table 2 may be considered. For instance, it is possible to postulate that certain classes of protective weapons are of an anti-deterrent nature in that they reduce the deterrent capabilities of an enemy alliance, for example anti-ballistic missiles. If deterrence is a pure public good, then, by implication, anti-deterrence is also purely public to the alliance (Sandler, 1977:447). Similarly, benefits perceived to be private, such as tertiary education for members of one particular ally's defence force may, in fact, be public if such training serves to improve the overall level of expertise and proficiency in the command structure and therefore efficacy of the alliance (Sandler, 1977:457). However, the exclusion of these and similar possibilities does not detract from the universal validity of the model.

In order to present a theoretical investigation of alliance formation which takes cognisance of the varying degrees of publicness of defence goods, a number of assumptions are made:

- Each member of the alliance produces, besides private non-defence goods, pure public, impure public and private defence goods.

- Deterrent defence goods are purely public between allies inasmuch as they are totally non-rival in consumption and their benefits are non-excludable.

- In the case of private defence goods total rivalry and excludability are displayed. 
- Protective defence goods exhibit varying degrees of rivalry and excludability.

Any given member of the alliance is assumed to jointly produce, in any given year, private defence goods, $\mathrm{x}$; pure public defence (deterrence) goods, $\mathrm{y}$; and impure public defence goods, z (modified and expanded from Murdoch and Sandler, 1984; Hansen et al, 1990; and Hilton and Vu, 1991). Military activity is denoted by q. The joint product relationships are

$$
\begin{aligned}
& \mathrm{X}=f(\mathrm{q}) \\
& \mathrm{Y}=\mathrm{g}(\mathrm{q}) \\
& \mathrm{z}=h(\mathrm{q})
\end{aligned}
$$

The production of non-defence private goods is determined by non-military activity, w.

Since deterrence is purely public, each ally receives the deterrence that it provides, as well as the deterrence that other alliance members provide. Thus, when choosing its own level of military activity an ally takes into account the amount of deterrence provided by the remaining members of the alliance. These deterrence spillins (the term used by Murdoch and Sandler, 1986) are the difference between the total deterrence provided by all the members of the alliance, and the deterrence produced by the ally, so that

$$
\mathrm{Y}=\mathrm{Y}^{*}+\mathrm{y}
$$

where $\mathrm{Y}$ denotes the alliance-wide deterrence, and $\mathrm{Y}^{*}$ the deterrence spillins.

The level of $\mathrm{Y}^{*}$ is determined by the military activities $(\mathrm{Q})$ of the remaining allies, ie,

$$
\mathrm{Y}^{*}=k(\mathrm{Q})
$$

The utility function of the ally can now be described as:

$$
\begin{aligned}
\mathrm{U} & =U(\mathrm{w}, \mathrm{x}, \mathrm{Y}, \mathrm{z}) \\
& =U\left(\mathrm{w}, \mathrm{x}, \mathrm{Y}^{*}+\mathrm{y}, \mathrm{z}\right)
\end{aligned}
$$

Substituting (1), (2), (3) and (5) in (6) yields

$$
\mathrm{U}=U(\mathrm{w}, f(\mathrm{q}), h(\mathrm{q}), k(\mathrm{Q})+g(\mathrm{q}))
$$

Thus, the determinants of an ally's utility are the activities $w, q$ and $Q$. The choice of activity levels is assumed to be constrained by a linear budget constraint (see, for example, Hansen, et al, 1990:40), viz.:

$$
\mathrm{I}=\mathrm{w}+\mathrm{pq}
$$

where I is the ally's income and $\mathrm{p}$ is the cost per unit of military activity. (The cost per unit of non-military activity, $\mathrm{w}$, is assumed to be unity.)

It follows intuitively that an ally's demand for military activity, q, is determined by its income; the cost per unit of military activity, p; and the extent of the military activities of other allies, Q. Thus

$$
\mathrm{q}=q(\mathrm{I}, \mathrm{p}, \mathrm{Q})
$$

Assuming that military activities bear the same characteristics as normal goods, it follows that $\mathrm{Dq} / \mathrm{DI}$ is positive. However, this positive income effect may be either neutralised or reinforced by exogenous changes in the quantity constraints encapsulated in Q. Consequently, a brief examination of the behaviour of $\mathrm{Dq} / \mathrm{DQ}$ (ie, the effect of other 
allies' military activities on an ally's own demand for military activity) under different sets of circumstances related to substitutability, is called for.

If, for instance, an ally's public defence goods (y) are a substitute for the total alliance deterrence $(\mathrm{Y})$, in the sense that they serve similar purposes, the number of units of private non-defence goods $(w)$ that the ally will be willing to exchange for an additional unit of $y$ (ie, the $\mathrm{MRS}_{\mathrm{yw}}$ ) will fall as the benefits accruing from $\mathrm{Y}$ due to an increase in $\mathrm{Q}$ rise. This will result in a reduction in the ally's propensity to supply its own defence needs, so that $\mathrm{Dq} / \mathrm{DQ}$ will tend to approach zero or even be negative. Consequently, the positive income effect may be neutralised or even outweighed by the substitution effect, and the ally may assume the characteristics of a free rider (whereby an ally relies to a large degree on others for its defence) within the alliance.

In the event of $\mathrm{y}$ and $\mathrm{Y}$ being complements (ie, the two defence outputs enhance one another's benefits) Dq/DQ may be assumed to be positive so that the substitution effect serves to reinforce the income effect. In this case there is unlikely to be evidence of free riding.

Free riding is not postulated in the event of private defence outputs, owing to the rivalry and excludability characteristics of such goods. Similarly, in the case of impure public defence goods, the degree of substitutability is limited owing due to dilution, so that $\mathrm{Dq} / \mathrm{DQ}$ is expected to be positive and free riding more limited than in the case of pure defence goods.

It would appear, therefore, that free riding is, in essence, determined by the degree of substitution between, on the one hand, the various kind of defence goods produced by the ally and, on the other, the total alliance-wide deterrence. The phenomenon of dilution militates against the likelihood of free riding in respect of impure public defence goods. However, substitution may be possible in the case of pure public defence (deterrence) goods.

\section{THE BUDGETARY CONSEQUENCES FOR SOUTH AFRICA OF SECURITY CO-OPERATION}

The position of South Africa regarding free riding within a potential military alliance will be determined by the strategic and geographical composition of her allies. In this regard three possible alliances are considered, viz. an alliance with

- Southern African nations;

- South American nations; and

- India and Pakistan.

In an alliance with neighbouring states in Southern Africa a disproportionate deterrence-sharing burden is predicted on grounds of the fact that South Africa is the leading producer and operator of conventional deterrence (and therefore public good) weapons in 
the sub-continent. Consequently, it is postulated that the military and economically weaker members of such an alliance would tend to be free riders at the expense of South Africa in particular.

An alliance with South American nations would probably have a neutral impact on the distribution of the deterrence burden. The degree of substitutability would be somewhat limited due to dilution. Thus, although similar in nature and purpose, the dilution of forces emanating from geographical distance would probably prevent free riding by either South Africa or South American allies.

The possibility of an alliance with India and/or Pakistan raises an interesting issue by virtue of the fact that India (and possibly Pakistan as well) has a nuclear capability. Nuclear allies have to allocate defence expenditure to both conventional and strategic (nuclear) weapons, where the latter are also assumed to provide deterrence and are therefore purely public (Murdoch and Sandler, 1984:89-91). Consequently, nuclear allies have an additional substitution possibility, inasmuch as their conventional weapons may feasibly be replaced by those produced by the non-nuclear allies. Thus, India may be tempted to reduce her production of conventional weapons, resulting in a greater relative burden being imposed in this regard on South Africa. However, as in the case of the South American option, substitution would probably be largely non-feasible due to dilution of forces, so that free riding by India is likely to be minimal. If a significant portion of South Africa's future deterrence strategy were to be based on a nuclear capability, an alliance with India would, to a large extent, obviate the need for an own nuclear programme and, in effect, South Africa would be able to free ride within the alliance. However, this may be offset by an increase in spending on conventional armaments induced by a desire not to be per-

\begin{tabular}{|c|c|c|}
\hline Potential allies & Substitution effect & Comment \\
\hline Southern African states & $\mathrm{Dq}_{\mathrm{sa}} / \mathrm{DQ}>0 *$ & $\begin{array}{l}\text { Free riding by Southern African } \\
\text { states }\end{array}$ \\
\hline South Amertcan states & $\mathrm{Dq}_{\mathrm{sa}} / \mathrm{DQ}=0$ & No free riding \\
\hline IndiarPakistan & $\mathrm{Dq}_{\mathrm{sa}} / \mathrm{DQ}<0$ & $\begin{array}{l}\text { Possible free riding by South } \\
\text { Africa }\end{array}$ \\
\hline $\begin{array}{l}{ }^{*} \mathrm{q}_{\mathrm{sa}}= \\
\mathrm{Q}=\end{array}$ & activities of ot & $\begin{array}{l}\text { Africa } \\
\text { mbers of the alliance }\end{array}$ \\
\hline
\end{tabular}

Table 3: The potential impact on South Africa's relative military burden in the event of alliance formation with various sub-regions

ceived as a weak member of the alliance.

\footnotetext{
SECURITY CO-OPERATION IN SOUTHERNAFRICA: NON-MILITARY CONSIDERATIONS
} 
In the final analysis, the decision as to whether to engage in security co-operation with other Southern African states may be influenced by considerations unrelated to the economics of free-riding and substitution.

The economic and socio-economic stagnation and even decline of the majority of African countries over the last three to four decades is well-chronicled. Rapid population growth, political instability, inappropriate economic policies, inappropriate production (Africa generally produces what it does not consume, and consumes what it does not produce), high and rising debt burdens, warped educational patterns, and inclement weather patterns, have all contributed to the distress of the continent.

Despite (and, in some cases, maybe because of) numerous attempts by African leaders to institute liberalist reforms (eg, democratic principles, neo-liberalist structural adjustment programmes), there is in some quarters a dystopian view that Africa is becoming ever more peripheral in the global economy, and is doomed to further poverty, immiserisation and ostracization.

Within the Southern African region the South African economy and, in many instances, her state of development, stands out like a shining beacon. South Africa's outperformance

\section{South Africa's economy and socio-economy vis-â-vis Southern Africa}

- Although South Africa is home to only 39 per cent of the region's total population, it is responsible for 80 per cent of the region's gross domestic product (GDP)

- South Afruca's economy is more than four times larger than the total of all the other economies in the region.

- South Africa produces 90 per cent of all manufactured goods in the regron.

- The Northem Cape province (the smallest economy in South Africa) has a larger economy than Mozambiqtte, Malawi, Lesotho and Swaziland.

- Only one comnty in the region has a larget economy thant that of the Free State (the fouth smallest provincial economy in South Afica).

- South Africa has the highest GNP per capita in the regron.

- South Africa's human development index is sumpassed only by that of Botswana (whose econony, however, is 30 mmes smaller than that of South Africa).

Sources: WEFA Group. 1997. Provincial Comparisons. South African Competitiveness Monitor, 1996, Vol 4. Pretoria: WEFA Group.

World Bank. 1996. World Development Report 1996. New York: Oxford University Press. 
of most, if not all, of her neighbours in terms of a number of indicators of economic and socio-economic performance is illustrated in Exhibit 1.

Two major forces are clearly emerging from the major divide between South Africa and other countries on the sub-continent. On the one hand, the inability to scratch out even a meagre living in a vast economic wasteland is compelling millions of hungry, poverty stricken inhabitants to seek greener pastures elsewhere (push-forces). To most, South Africa represents those greener pastures (pull-forces). Hence, the annual influx into South Africa of hundreds of thousands of what have become called 'illegal immigrants', fleeing, from what Paul Kennedy terms the 'third world's third world'.

The impact of this inflow can be summarised as follows. Economic refugees from elsewhere in Southern Africa are exerting considerable pressure on an already explosive demographic situation in South Africa. With more and more people seeking fewer and fewer jobs, and laying claim to the country's strained resources, the potential for violent conflict is obvious. In short, South Africa's real or perceived superior economic performance and prospects relative to the rest of Africa are making a contribution to the high incidence of unemployment and potential societal disintegration in South Africa.

As long as there are regional disparities in the sub-continent there will be an inevitable influx of illegal immigrants for many years to come. Thus, it is within South Africa's interest to make a meaningful contribution to economic development and enhanced prosperity in all Southern African countries. It is better to import goods and services than socio-political instability.

In the final analysis, the decision as to whether to enter an alliance and with whom, may be influenced by considerations unrelated to the economics of free riding and substitution. Thus, in the Southern African region with a secular vulnerability to the threat of socio-economic and even political collapse, South Africa, as the major power, has a vested interest in averting a threat to even one nation. Given the limited resources in the region, co-operation and some form of defence alliance would promote security and, by implication, stability which, in turn, would serve the economic interests of all the members. Moreover, by entering into an alliance with other countries in Southern Africa, South Africa could feasibly make a significant contribution to the overall collective welfare of those members of the alliance. By consuming security provided by the rest of the alliance and, in particular, South Africa, the security effort demanded by the individual smaller country is smaller. Consequently, resources are released for the production and consumption of civilian goods and services. The country therefore has a higher level of security than before, as well as a greater volume of civilian goods.

The influence on South Africa's defence burden of an alliance formation will largely be determined by the identity of such allies. Security co-operation in Southern Africa could result in a higher defence burden for South Africa as other members would be tempted to free ride. However, in this fashion South Africa could feasibly make a significant contribution to the overall collective welfare of those members of the alliance, granting them a 
higher level of security than before, as well as a greater volume of civilian goods.

\section{CONCLUSION}

The deterrence component of defence spending is generally a pure public good for a specific country, but engagement in actual hostilities will not necessarily be a public good to all the inhabitants of a country. By extending the analysis to alliances it was found that, in the event of South Africa entering into an alliance with Southern African states, the country would bear a relatively larger portion of the defence burden than the remaining allies. However, South Africa might be able to reduce its military burden by entering into an alliance with India and/or Pakistan.

As the most powerful economic and military nation in Southern Africa (and, indeed, in Africa), the role of South Africa in reversing the (to some) inevitable marginalisation of the region is a pivotal one. This role could and should assume various guises: as an exporter to the region, as an investor in the region, and - as has been proposed in this paper - as a supplier of security. The latter may, at least in the short run, entail higher defence burdens for South Africa. If, however, it results in the freeing up of resources in other countries in the region, the longer term benefits for South Africa should outweigh the shorter term costs. A sine qua non for this kind of result is, of course, that the resources thus released be used in a productive and meaningful fashion, eg, for investment in physical and human infrastructure.

\section{References}

Boyer, MA 1990. A simple and untraditional analysis of Western alliance burden-sharing. Defence economics: The political economy of defence disarmament and peace, Vol 1(3).

Davis, DR \& Chan, S. 1990. The security-ẉelfare relationship: Longitudinal evidence from Taiwan. Journal of Peace Research, Vol 27(1).

Deger, S. 1986. Military expenditure in Third World countries: The economic effects. London: Routledge \& Kegan Paul.

Hansen L, Murdoch, JC \& Sandler, T. 1990. On distinguishing the behaviour of nuclear and nonnuclear allies in the NATO. Defence Economics: The Political Economy of Defence Disarmament and Peace, Vol 1(1).

Hilton, B \& Vu, A. 1991. The McGuire model and the economics of the NATO alliance. Defence Economics: The Political Economy of Defence Disarmament and Peace, Vol 2(2).

Lotz, JR. 1970. Patterns of government spending in developing countries. Manchester School. 
Maizels, A \& Nissanke, MK. 1986. The determinants of military expenditures in developing countries. World Development, Vol 14(9).

McGuire, MC. 1990. Mixed public-private benefit and public-good supply with application to the NATO alliance. Defence Economics: The Political Economy of Defence Disarmament and Peace, Vol 1(1).

McKinlay, RD. 1989. Third World military expenditure: Determinants and implications. UK: Printer Publishers.

Murdoch, JC \& Sandler, T. 1984. Complementarity, free riding, and the military expenditures of NATO allies. Journal of Public Economics, Vol 25:83-101.

Olson, M \& Zeckhauser, R. 1966. An economic theory of alliances. Review of Economics and Statistics, Vol 48:237-263.

Pilandon, L. 1987. Quantitative and causal analysis of military expenditures. In Schmidt, C (Ed). The economics of military expenditures. Proceedings of a conference held by the International Economic Association in Paris, France. New York: St Martin's Press.

Sandler, T. 1977. Impurity of defense: An application to the economics of alliances. Kyklos, Vol $30: 443-460$.

Smith, RP. 1980. The demand for military expenditure. The Economic Journal, Vol 90.

WEFA Group. 1997. Provincial Comparisons. South African Competitiveness Monitor, 1996, Vol 4. Pretoria: WEFA Group.

Whynes, DK. 1979. The economics of Third World military expenditures. Austin: University of Texas Press.

World Bank. 1996. World Development Report 1996. New York: Oxford University Press. 